\title{
Optimal foraging in chick-raising Common Guillemots (Uria aalge)
}

\author{
Julie Bugge $\cdot$ Robert T. Barrett • Torstein Pedersen
}

Received: 27 April 2010/Revised: 23 June 2010/Accepted: 6 August 2010/Published online: 27 August 2010

(C) The Author(s) 2010. This article is published with open access at Springerlink.com

\begin{abstract}
The Norwegian population of the Common Guillemot Uria aalge has declined by $>95 \%$ since the 1960 s, and is classified as critically endangered in the Norwegian Red List. Much of the recent decline has been attributed to reduced food availability, but without extensive documentation of adult diet. Instead, chick diet has been considered a proxy of adult diet during the breeding season in many Norwegian studies. However, central-place foraging theory, especially for single-prey loaders, predicts that this may not be so, and this study directly compares the diet of adult and chick Common Guillemots during the breeding season at a colony in NE Norway. Whereas chicks were fed mainly capelin (Mallotus villosus) and sandeels (Ammodytes sp.), most of the adult diet consisted of the two youngest year classes of Gadidae, probably cod (Gadus morhua) and haddock (Melanogrammus aeglefinus). A successful ecosystem management of seabirds is dependent on a full understanding of how prey quality, abundance and availability influence seabird populations and their viability, such that knowing the true diet of adult Common Guillemots has important implications in the modelling and management of the Norwegian populations.
\end{abstract}

Communicated by P. H. Becker.

\author{
J. Bugge $\cdot$ R. T. Barrett $(\square)$ \\ Department of Natural Sciences, Troms $\emptyset$ University Museum, \\ 9037 Troms $\varnothing$, Norway \\ e-mail: rob.barrett@uit.no \\ J. Bugge $\cdot$ T. Pedersen \\ Department of Arctic and Marine Biology, \\ Faculty of Biosciences, Fisheries and Economics, \\ Troms $\varnothing$ University, 9037 Troms $\varnothing$, Norway
}

Keywords Common Guillemot - Uria aalge - Optimal foraging · Food

\section{Introduction}

The Common Guillemot (Uria aalge) is a widespread, circumpolar, boreal and low Arctic species. Although numerous in the North Atlantic (ca. 3 million breeding pairs) and generally increasing in numbers after years of human persecution, the Norwegian population has declined by $>95 \%$ since the 1960 s to ca. 15,000 pairs in 2005 (Gaston and Jones 1998; Barrett et al. 2006). This decline was initially a result of direct and indirect human pressure, but subsequent breakdown of social structure and harassment from White-tailed Eagles (Haliaeetus albicilla) exacerbated the situation causing several colonies to be in danger of extinction (Barrett et al. 2006; Erikstad et al. 2007). The Common Guillemot is consequently classified as critically endangered in the Norwegian Red List (Kålås et al. 2006).

The vast majority of seabird feeding ecology studies has been restricted to breeding sites and seasons when birds are easy to access (Shealer 2002). Since seabirds spend most of the year at sea, such short-term sampling results in bias when evaluating the overall impact of food availability on population dynamics. This is exacerbated by the fact that most colony-based studies are of chick diet, and that the comparatively few studies that have directly compared the diets of breeding adults to those of chicks (or non-breeding adults) have revealed substantial differences (e.g. Ydenberg 1994; Brown and Ewins 1996; Davoren and Burger 1999; Dierschke and Hüppop 2003; Wilson et al. 2004).

This difference is partially due to constraints such as number of prey brought to the chick, size of prey and 
distance to foraging grounds. These constraints lead to a differentiation between prey eaten by adults and prey that are most profitable regarding size and energetic content for chick rearing. During the breeding season, parent birds have to optimally allocate their resources between sustaining themselves and their chick(s). Central-place foraging theory (Orians and Pearson 1979) predicts that adults should maximise energy yield per unit foraging effort and thus their chick's energy gain per unit time. For single-prey loaders (such as guillemots Uria spp.), this might be obtained by bringing larger and more energy-rich prey to their chicks than they eat themselves (i.e. adults should be more selective regarding chick food than food for themselves). Thus, the allocation of food between the parents and the chicks could take the form of optimal sharing, with the threshold being determined by the relative needs of the parents and their chick(s) (Wilson et al. 2004; Sonntag and Hüppop 2005; McLeay et al. 2009).

In the 1986/1987 winter, food shortages caused a die-off of adult birds and a serious decline in the population of Common Guillemots in Norway (e.g. Vader et al. 1990; Barrett and Krasnov 1996). It was assumed then that the cause was a collapse in the capelin (Mallotus villosus) stocks in the Barents Sea. However, while detailed, longterm studies of chick diet are in progress in Norway, little is known about adult diet. Small, energy-rich fish such as capelin, I-group herring (Clupea harengus) and sandeels (Ammodytes sp.) are well documented as important chick food in N Norway and NW Russia (Barrett et al. 1997; Barrett and Golovkin 2000; Barrett 2002), but adults have also been shown to feed on euphausiids and gadids (AnkerNilssen and Nygård 1987; Barrett et al. 1997; Mehlum 2001). Because the need to return regularly to the colony constrains adult foraging to a maximum during the breeding season, improved knowledge of adult diet during the breeding season is required for more precise predictive modelling and better management of this threatened population (Erikstad et al. 2007). For example, a better documentation of adult diet would help clarify the relationships between Common Guillemot population dynamics, prey availability and fisheries in Norwegian waters.

In 2003, Wilson et al. (2004) tested the foraging theory and prediction that adult Common Guillemots would bring better quality prey to their chicks than they ate themselves, and were the first to directly compare adult and chick diet in the same colony. They found that adults did indeed feed on smaller prey items, mainly 0-group lesser sandeels A. marinus whereas chicks were fed energy-rich sprats Sprattus sprattus and adult lesser sandeels. Their study was in a region where sandeels are the dominant prey among breeding seabirds whereas this study tested the same prediction in a region where capelin and small herring are also dominant prey (Barrett and Furness 1990; Barrett et al. 2002).

\section{Methods}

The study was carried out during the hatching and main chick-rearing period in a colony of ca. 8,000 pairs of Common Guillemots (RT Barrett, unpublished data) on Hornøya $\left(72^{\circ} 22^{\prime} \mathrm{N}, 31^{\circ} 10^{\prime} \mathrm{E}\right)$, a small island in NE Norway between 16 June and 17 July 2008. One hundred and two adults were caught using a noose pole as they came in with fish for the chick. All birds were ringed, weighed $( \pm 5 \mathrm{~g})$ and measured (wing, culmen and head + bill lengths $\pm 0.5 \mathrm{~mm}$ using a stopped wing rule and vernier calipers), a small blood sample ( $\max .50 \mu \mathrm{l})$ was taken from the brachial vein for later sex determination, and a stomach content sample obtained using the water off-loading method as described by Wilson et al. (2004). Each adult was flushed a maximum three times to ensure a complete emptying of the stomach, and was finally marked with a felt-tipped pen to avoid unnecessary recapture. On release, some birds flew down to the sea before returning to the nest site after a short time whereas others scrambled down the slope and returned immediately to their chick. There was no evidence that the handling of the birds caused any harm, as also found by Wilson et al. (2004). The off-loaded food remains were stored in a plastic bag, marked, and deep-frozen for later analysis. When possible, the fish being carried by the adult was also collected and individually frozen.

After thawing, a preliminary identification to lowest possible taxon of undigested remains [mainly otoliths, fish scales and pro-otic bullae (characteristic for herring) and fish eggs (characteristic for capelin)] in the stomach samples was noted (using Härkonen 1986; Watt et al. 1997; and our own reference collection). The samples were then further digested in a saturated solution of biological washing powder $\left(\right.$ Biotex $\left.^{(}\right)$in an oven at $50^{\circ} \mathrm{C}$ for at least $24 \mathrm{~h}$ after which additional otoliths were identified. Because otoliths of cod (Gadus morhua), saithe (Pollachius virens) and haddock (Melanogrammus aeglefinus) (the three most likely gadids to be caught off Hornøya) are extremely difficult to distinguish when small, they were initially classified as gadid (family Gadidae). The lengths and widths of all otoliths were measured using a calibrated eye-piece graticule in a binocular microscope and used to determine total fish lengths (FL) using equations in Barrett and Furness (1990) for capelin and Jobling and Breiby (1986) for sandeel that are both based on fish caught in the southern Barents Sea. Because Jobling and Breiby's (1986) equation is based on standard fish length, the results were converted to total fish length using a factor of 1.01 (based on own measurements). For the gadids, three alternative equations were used to estimate their size, one for each of the three likely species (Table 1). These equations were based on our own measurements of otoliths and fish caught in the region and gave similar results for the youngest year 
Table 1 Polynomial coefficients of relationships between otolith width (OW) and total fish length (FL) based on measurements of fish caught in the southern Barents Sea

\begin{tabular}{lrrrr}
\hline & $\mathrm{a}$ & $\mathrm{b}$ & $\mathrm{c}$ & \multicolumn{1}{c}{$\mathrm{d}$} \\
\hline Cod Gadus morhua & 1.079 & 4.293 & 1.521 & -0.110 \\
Saithe Pollachius virens & -3.805 & 12.269 & -1.012 & 0.412 \\
Haddock Melanogrammus & 2.357 & 4.704 & -0.372 & 0.104 \\
aeglefinus & & & & \\
\hline
\end{tabular}

$\mathrm{FL}=\mathrm{a}+\mathrm{b} \times \mathrm{OW}+\mathrm{c} \times \mathrm{OW}^{2}+\mathrm{d} \times \mathrm{OW}^{3}$

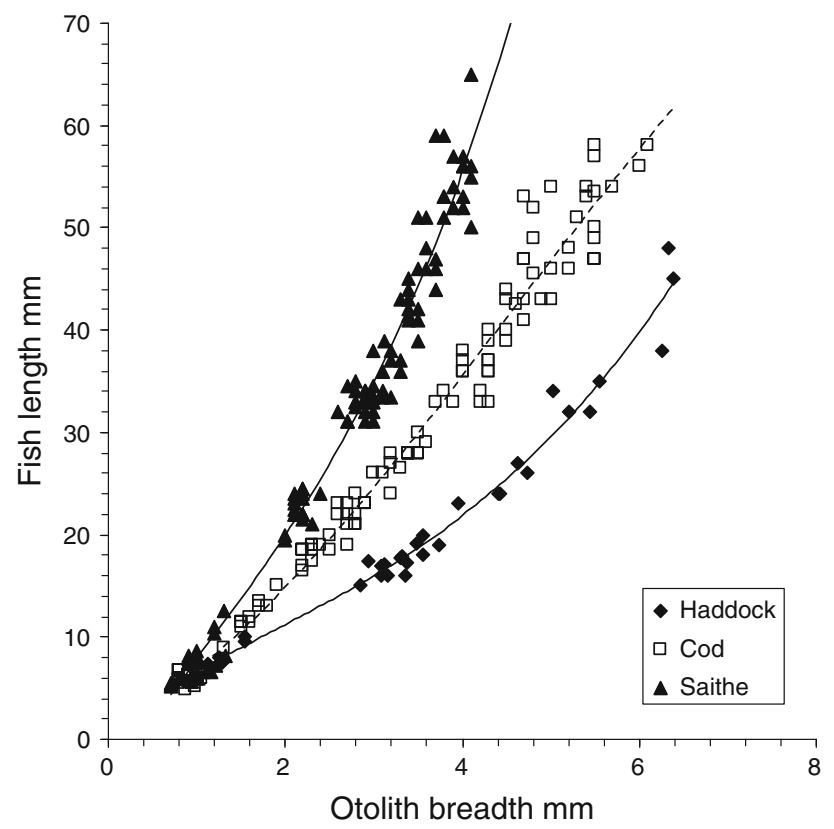

Fig. 1 Relationship between total fish length and otolith breadth for three species of gadid, haddock (Melanogrammus aeglefinus), saithe (Pollachius virens) and cod (Gadus morhua) based on measurements of specimens from the southern Barents Sea (T Pedersen, unpublished data). (Equations for trend lines in Table 1)

class of fish (0-group) but were more critical for older fish (Fig. 1).

Diet composition is expressed as frequency of occurrence based on counts of taxa in each sample. It was impossible to improve this quantification due to large differences in the degree of digestion of the samples and the uncertainty as to how many meals each regurgitation represented. To avoid possible pseudoreplication through possible diet specialization by individual birds (Woo et al. 2008), only one diet sample (stomach and/or chick) was collected from an adult. Means are given \pm 1 standard deviation. Differences in diet between adults and chicks were tested using Chi-square $\left(\chi^{2}\right)$ goodness of fit of all the samples, supplemented by a sign-test for paired (adult and chick) sample comparisons (Zar 1999), when a stomach and chick food sample was collected from the same adult. Differences in mean lengths of prey were tested using Student's $t$ test.
Table 2 Frequency of occurrence of prey types in the diet of Common Guillemot (Uria aalge) adults and chicks at Hornøya, North Norway, 2008

\begin{tabular}{|c|c|c|c|c|}
\hline \multirow[t]{2}{*}{ Prey type } & \multicolumn{2}{|l|}{ Adult $(n=59)$} & \multicolumn{2}{|l|}{ Chick $(n=79)$} \\
\hline & $\begin{array}{l}\text { No. of samples } \\
\text { containing prey } \\
\text { type }\end{array}$ & $\begin{array}{l}\% \text { of } \\
\text { samples }\end{array}$ & $\begin{array}{l}\text { No. of samples } \\
\text { containing prey } \\
\text { type }\end{array}$ & $\begin{array}{l}\% \text { of } \\
\text { samples }\end{array}$ \\
\hline Gadid & 53 & 89.8 & 2 & 2.5 \\
\hline Capelin & 15 & 25.4 & 65 & 82.3 \\
\hline Sandeel & 7 & 11.9 & 10 & 12.6 \\
\hline Herring & $10^{\mathrm{a}}$ & 16.9 & 2 & 2.5 \\
\hline Squid & 1 & 1.7 & 0 & 0 \\
\hline
\end{tabular}

${ }^{\text {a }}$ Including one with herring larvae

\section{Results}

Fifty-nine $(58 \%)$ of the 102 stomach samples contained enough material to be included in the analyses and 79 fish carried by the adults were collected. The remaining fish were lost on capture among the birds on the breeding shelf.

Adult and chick diet composition

Of the 59 adult stomach samples, 56 contained 1-56 otoliths $($ mean $=7.1 \pm 8.8), 4$ contained only herring bullae and 6 both otoliths and bullae. No herring otoliths were found. Gadids were the most frequent prey, being found in $53(89.8 \%)$ of the 59 samples. Capelin was found in $25.4 \%$ and sandeels in $11.9 \%$ of the samples (Table 2).

Of the 79 fish collected that were meant for chicks, 65 $(82.3 \%)$ were capelin, $10(12.6 \%)$ were sandeels, $2(2.5 \%)$ were gadids and $2(2.5 \%)$ were herring (Table 2$)$.

There was a clear difference in diet of the adults and their chicks with adults eating mainly gadids while the chicks were fed mostly capelin and sandeel $\left(\chi^{2}=53.2, d f=4\right.$, $P<0.001)$. Using paired samples $(n=57)$, the frequency of occurrence (FO) of capelin in chick food (77.2\%) was significantly higher than that in adult stomachs $(26.3 \%$, sign-test, $P<0.001)$. In contrast, for gadoid prey, the FO in the diet of adults $(91.2 \%)$ was higher than for chicks $(3.5 \%)$ $(P<0.001)$. For herring, FO was also higher $(19.3 \%)$ for adults than for chicks $(1.8 \%)(P=0.006)$, whereas for sandeel, the FO for adults $(10.5 \%)$ did not differ significantly from that of chicks $(17.5 \%)(P=0.45)$.

Size distribution of prey

The mean lengths of the capelin and sandeels fed to chicks were 141.6 and $125.4 \mathrm{~mm}$, respectively and were significantly larger than those eaten by the adults (by 30 and $12 \mathrm{~mm}$, respectively, Student's $t$ test, $P<0.05$; Table 3). 
Table 3 Size of capelin and sandeels eaten by adults and those caught to feed to chicks of Common Guillemots (Uria aalge) at Hornøya, North Norway, 2008

\begin{tabular}{|c|c|c|c|c|c|c|c|c|}
\hline & \multicolumn{4}{|c|}{ Capelin } & \multicolumn{4}{|c|}{ Sandeel } \\
\hline & $\begin{array}{l}\text { Mean } \\
(\mathrm{mm})\end{array}$ & SD & $\begin{array}{l}\text { Range } \\
(\mathrm{mm})\end{array}$ & $n$ & $\begin{array}{l}\text { Mean } \\
(\mathrm{mm})\end{array}$ & SD & $\begin{array}{l}\text { Range } \\
(\mathrm{mm})\end{array}$ & $n$ \\
\hline Adult & 111.5 & 14.2 & $89-131$ & 12 & 113.3 & 22.9 & $64-156$ & 29 \\
\hline \multirow[t]{2}{*}{ Chick } & 141.6 & 14.2 & $99-168$ & 65 & 125.4 & 9.5 & $113-136$ & 10 \\
\hline & \multicolumn{4}{|c|}{$t=-6.75, P<0.001$} & \multicolumn{4}{|c|}{$t=-2.31, P=0.027$} \\
\hline
\end{tabular}

The gadids eaten by the adults fell into two distinct size groups, irrespective of which species is considered (Fig. 2). The majority (76\% of 340 otoliths) fell within a common 20-80 mm group ( $\equiv 0$-group cod, saithe and haddock) but in separate species groups for the larger fish; $140-200 \mathrm{~mm}$ for haddock, $220-290 \mathrm{~mm}$ for cod, and $300-410 \mathrm{~mm}$ for saithe. The two gadids fed to chicks were 52 and $65 \mathrm{~mm}$, i.e. also 0 -group fish.

Whereas there was no change in size of capelin and sandeels fed to chicks during the period of the study, the mean size of both species eaten by the adults decreased considerably (capelin: $r^{2}=0.43, P=0.029, \quad n=11$; sandeel: $\left.r^{2}=0.64, P<0.001, n=29\right)$ (Fig. 3). Similarly and using haddock as the most likely prey (see
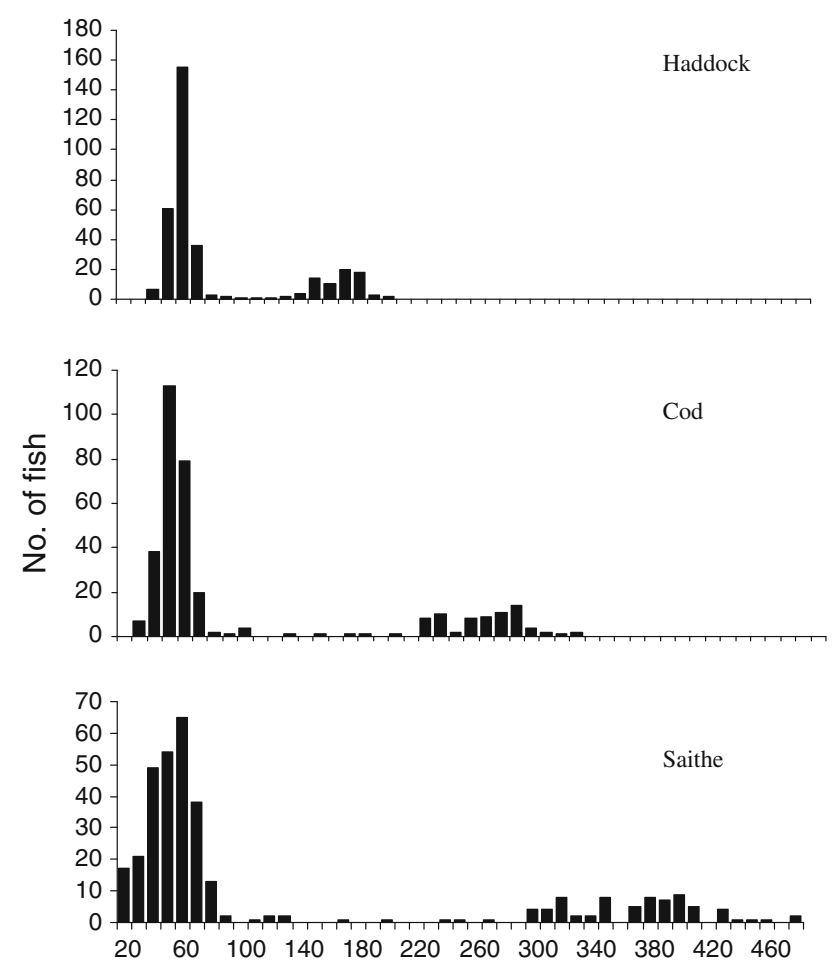

Fish length $\mathrm{mm}$

Fig. 2 Size distributions of gadids possibly eaten by adult Common Guillemots (Uria aalge) at Hornøya, N Norway, 2008 (using alternative equations for cod, saithe and haddock; Table 2)

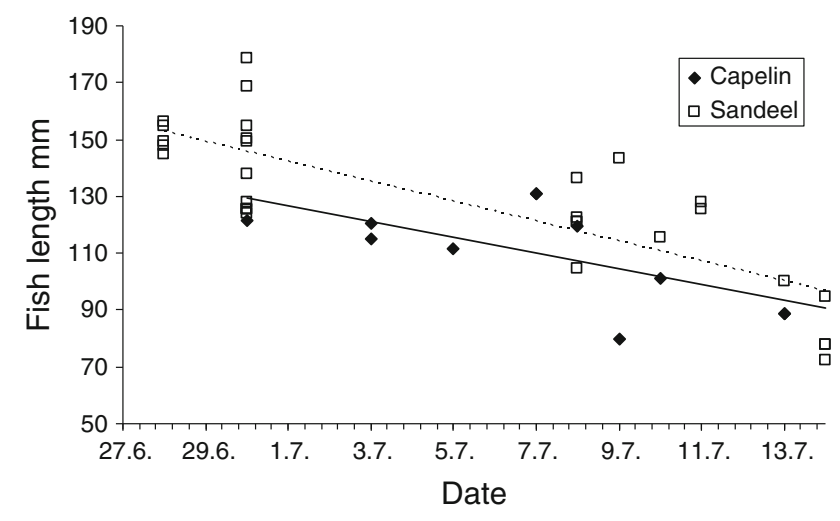

Fig. 3 Estimated lengths of capelin and sandeels eaten by adult Common Guillemots (Uria aalge) in relation to date at Hornøya, North Norway, 2008

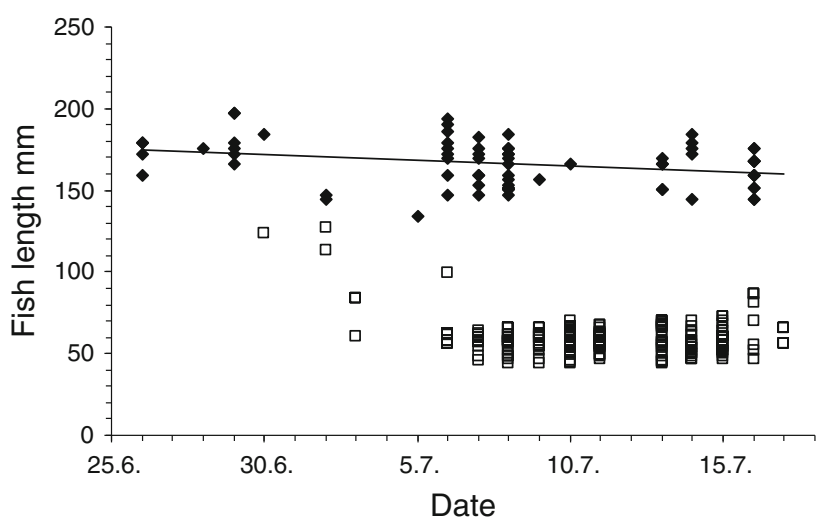

Fig. 4 Estimated lengths of gadids (using equation for haddock) eaten by adult Common Guillemots Uria aalge in relation to date at Hornøya, North Norway, 2008. Squares fish $<130 \mathrm{~mm}$, diamonds fish $>130 \mathrm{~mm}$. The trend line is fitted to fish $>130 \mathrm{~mm}$ only

"Discussion"), the size of the largest ( $>130 \mathrm{~mm})$ gadids dropped slightly as the season progressed $\left(r^{2}=0.08\right.$, $P=0.013, n=72$ ) while that of the 0-group fish $(<80 \mathrm{~mm})$ that appeared about halfway through the study period did not change (Fig. 4).

\section{Discussion}

Wilson et al. (2004) were probably the first to use the water off-loading method on a species that does not normally regurgitate, and had a success rate of $68 \%$, i.e. 62 samples from 91 adults caught. Although the success rate of this study $(58 \%)$ was a little lower, the observed rapid return rates of the adults to the nest site after treatment shows that, at least for Common Guillemots, the method can be recommended. The use of skeletal remains and otoliths to identify and estimate size of prey does, however, have limitations due to differential retention times of different prey types and differential digestion rates of otoliths (e.g. 
Jobling and Breiby 1986; Johnstone et al. 1990; Wilson et al. 2004; Barrett et al. 2007), but this bias in diet determination was partially overcome in this and Wilson et al.'s (2004) study by restricting the quantification of the data to frequency of occurrence. That said, few of the otoliths found in this study had signs of excess erosion and the majority were considered suitable for measurement and determination of fish size. The lack of herring otoliths in the samples, however, may be due to their small size and rapid digestion (Johnstone et al. 1990), but the species was represented by the bullae that are more resistant to digestion, and their presence in the samples precludes any underrepresentation of the species in the diet.

One unfortunate shortcoming in this study was the lack of a definitive identification of the gadids to species or even genus level. I-group cod and saithe can, however, be eliminated as having been too large for a Guillemot to handle in the quantities found (Fig. 1). Among the many published studies of adult Common Guillemot diet, very few document gadids $>200 \mathrm{~mm}$. Lorentsen and AnkerNilssen (1999) found only 1 (213.7 mm) among 156 unidentified gadids (Lorentsen, personal communication) whereas Ouwehand et al. (2004) found 9 among 75. In the latter study, most of the maximum lengths of eight named gadid species (totalling 102 fish) were 150-195 mm. Furthermore, Swennen and Duiven (1977) found that the height of gadid fish and not their length was the decisive factor. Fish preferred by Common Guillemots had a height of $23 \mathrm{~mm}$ and the largest fish a height of $41 \mathrm{~mm}$. With a length/height ratio of 4.78 for haddock (measured on 13 fish of relevant size; T Pedersen, unpublished data), these are equivalent to total fish lengths of ca. 110 and $196 \mathrm{~mm}$, respectively. This corresponds to the size interval for haddock in Fig. 2 and supports the elimination of cod and saithe as being among the larger fish caught by the Common Guillemots in this study. Haddock in the size range 140-190 $\mathrm{mm}$ (Fig. 2) are I-group fish, i.e. they hatched the previous year. With respect to the 0-group fish, all three species are common off Hornøya in summer, but cod are normally most abundant (T Pedersen, unpublished data).

Irrespective of the final identification, 0-group gadids are all much smaller and hence of poorer individual quality than the energy-rich prey fed to the chicks (e.g. Pedersen and Hislop 2001). The dominance of capelin and sandeels in the chick diet was corroborated by a contemporary but independent survey on Hornøya in which $75 \%$ of 1,360 fish observed being brought into the colony were capelin, $16 \%$ sandeel, $6 \%$ herring and 2\% "other" (R.T. Barrett, personal observation). The large differences between adult and chick diet supported the prediction that chicks would be fed larger and more energy-rich fish than the adults ate themselves. While both age groups ate capelin, sandeels, herring and gadids, the chicks were fed $>80 \%$ capelin and the adults ate $>60 \%$ gadid. This is in full accordance with Wilson et al. (2004) who found that Scottish adults ate mainly 0-group sandeels while $79 \%$ of the fish fed to the chicks were energy-rich sprats and 20\% I-group sandeels, and Sonntag and Hüppop (2005) who found that Helgoland adults fed their chicks a higher proportion of, and larger, sandeels and clupeids than they ate themselves. These findings all support the hypothesis that single prey-loading Common Guillemots maximise net energy gain per unit time for their chicks, as predicted by theories of optimal foraging (Orians and Pearson 1979; Thaxter et al. 2009).

It has long been thought that capelin is the main diet of Common Guillemots in North Norway, and that a 70-90\% collapse in the breeding population due to an extraordinary adult mortality in winter 1986/1987 was explained by a similar collapse in the capelin stocks (Erikstad 1990; Vader et al. 1990; Krasnov and Barrett 1995). Although capelin has since been shown to be a major prey of Common Guillemot in the region in early spring (Erikstad and Vader 1989), this study shows that other prey items such as 0-group gadids may be equally important. Prior to the collapse in Guillemot numbers in 1987, the adult stocks of cod in the Barents Sea had also dropped, from $>6$ million $t$ in mid-1942 to ca 1 million $t$ in 1987, and the index of year class abundance for 0-group cod was at a minimum in 1987 (Mehl 1991; Hopkins and Nilssen 1991). Similarly, the abundance of 0-group saithe and haddock were also at a minimum in 1987 (ICES Advice 2009, http://www.ices.dk/ advice/icesadvice.asp). During the time of the present study, the capelin stocks and 0-group abundance of the three gadids were high. Thus, the absence of small gadids, in addition to (or instead of) the collapse in the capelin stocks, may have played an important but previously unrecognized role in the extraordinary mortality of Common Guillemots in 1986/1987.

The dependence by adults on poorer quality prey than fed to chicks is corroborated by studies in the non-breeding season, i.e. away from the colonies and not connected to chick-provisioning. These studies suggest seabirds then take a larger variety of prey, including many species that are relatively low in energy density (e.g. Bradstreet and Brown 1985; Sonntag and Hüppop 2005; Hedd and Montevecchi 2006), and often at a lower trophic level (Bearhop et al. 2001). In Norwegian waters, Mehlum (2001) showed that Barents Sea Common Guillemots and Brünnich's Guillemots (Uria lomvia) that brought fish to their young had much smaller prey, e.g. euphausiids, as their own staple diet. Anker-Nilssen and Nygård (1987) also found that adult Common Guillemots accompanying chicks in mid-Norway soon after they had left the colony had fed mainly on gadids. In contrast, a study of food requirements by seabirds on Hornøya assumed that chick 
and adult diets were similar and that capelin was an important constituent $(50 \%)$ of adult diet (Furness and Barrett 1985). A later study of seabird consumption in Norwegian waters (Barrett et al. 2002) was based on the same assumption, even after evidence that adults may eat prey other than that fed to their chicks had been published (Anker-Nilssen and Nygård 1987; Mehlum 2001). Although not a large source of error considering the final figures, the fact that diet may vary considerably with time and that gadids are, at times, more important in the diet of Common Guillemots (and probably also other species) than previously considered means that such assumptions need to be reconsidered in future.

Although carried out in very different waters, this study corroborated that of Wilson et al. (2004) in its support of the prediction that adults ate poorer quality prey than that fed to their chicks, thereby providing further support for the central-place foraging theory. It also highlights the importance of including previously unrecognized prey types such as 0-group cod and I-group haddock (in addition to capelin, sandeels and young herring) in future models of consumption and population dynamics of the locally threatened Common Guillemots in North Norwegian waters, as well as raising the question as to whether other seabird species breeding in the region rely more on gadids than previously thought. In this region, where there are large changes in seabird populations and where forage fish populations fluctuate greatly (Barrett et al. 2006), a successful ecosystem management of seabirds is dependent on a full understanding of how prey quality, abundance and availability influence seabird populations and their viability (Österblom et al. 2008).

\section{Zusammenfassung}

\section{Optimale Nahrungswahl bei Küken aufziehenden} Trottellummen Uria aalge

Die norwegische Population der Trottellumme Uria aalge hat seit den 1960er Jahren um mehr als 95\% abgenommen, und diese Art wird in der norwegischen roten Liste als vom Aussterben bedroht geführt. Der Großteil der jüngsten Abnahme ist verminderter Nahrungsverfügbarkeit zugeschrieben worden, ohne jedoch die Nahrung von Altvögeln ausführlich zu dokumentieren. Stattdessen wurde in vielen norwegischen Studien die Kükennahrung als ein Maß für die Nahrung von Altvögeln während der Brutsaison betrachtet. Die Theorie des ,central place foraging“(wiederholte Rückkehr in dasselbe Nahrungsgebiet) sagt jedoch insbesondere für Arten, die nur ein einziges Beutestück transportieren, vorher, dass dies nicht unbedingt der Fall sein muss, und die vorliegende Studie vergleicht die
Nahrung von Küken und adulten Trottellummen während der Brutsaison in einer Kolonie in Nordostnorwegen direkt miteinander. Während die Küken hauptsächlich mit Lodde (Mallotus villosus) und Sandaalen (Ammodytes sp.) gefüttert wurden, bestand der Großteil der Nahrung von Altvögeln aus den beiden jüngsten Altersklassen von Dorschen (Gadidae), wahrscheinlich Kabeljau (Gadus morhua) und Schellfisch (Melanogrammus aeglefinus). Ein erfolgreiches Ökosystemmanagement von Seevögeln hängt von einem vollständigen Verständnis davon ab, wie Qualität, Abundanz und Verfügbarkeit von Beute Seevogelpopulationen und ihre Lebensfähigkeit beeinflussen, so dass eine Kenntnis der genauen Nahrung adulter Trottellummen wichtige Folgen für das Modellieren und das Management der norwegischen Populationen hat.

Acknowledgments We thank the Norwegian Coastal Administration for permission to use the lighthouse on Hornøya as our base for fieldwork and Tycho Anker-Nilssen (NINA, Trondheim) for obtaining permission from the Norwegian Animal Research Authority to take stomach samples. Svein-Håkon Lorentsen (NINA, Trondheim), Francis Daunt (CEH, Edinburgh) and two anonymous referees are thanked for their comments on earlier drafts of the manuscript. The study was financed by the University of Troms $\varnothing$ and the Norwegian SEAPOP programme (http://www.seapop.no). This study was performed under licence no. S-2008/33166 of the Norwegian Animal Research Authority.

Open Access This article is distributed under the terms of the Creative Commons Attribution Noncommercial License which permits any noncommercial use, distribution, and reproduction in any medium, provided the original author(s) and source are credited.

\section{References}

Anker-Nilssen T, Nygård T (1987) Notes on the food choice of adult and young guillemots Uria aalge during post-breeding migration in Central Norway. Fauna Norv Ser C Cinclus 10:53-56

Barrett RT (2002) Atlantic puffin Fratercula arctica and common guillemot Uria aalge chick diet and growth as indicators of fish stocks in the Barents Sea. Mar Ecol Prog Ser 230:275-287

Barrett RT, Furness RW (1990) The prey and diving depths of seabirds on Hornøy, North Norway after a decrease in the Barents Sea capelin stocks. Ornis Scand 21:179-186

Barrett RT, Golovkin AN (2000) Common Guillemot Uria aalge. In: Anker-Nilssen T, Bakken V, Strøm H, Golovkin AN, Bianki VV, Tatarinkova IP (eds) The status of marine birds breeding in the Barents Sea region, Norsk Polarinst Rap Ser No 113, Troms $\varnothing$, pp 114-118

Barrett RT, Krasnov YV (1996) Recent responses to changes in stocks of prey species by seabirds breeding in the southern Barents Sea. ICES J Mar Sci 53:713-722

Barrett RT, Bakken V, Krasnov JV (1997) The diets of common and Brünnich's guillemots Uria aalge and U. lomvia in the Barents Sea region. Polar Res 16:73-84

Barrett R, Anker-Nilssen T, Gabrielsen GW, Chapdelaine G (2002) Food consumption by seabirds in Norwegian waters. ICES J Mar Sci 59:43-57

Barrett RT, Lorentsen S-H, Anker-Nilssen T (2006) The status of breeding seabirds in mainland Norway. Atl Seabirds 8:97-126 
Barrett RT, Camphuysen CJ, Anker-Nilssen T, Chardine JW, Furness RW, Garthe S, Hüppop O, Leopold MF, Montevecchi WA, Veit RR (2007) Diet studies of seabirds: a review and recommendations. ICES J Mar Sci 64:1675-1691

Bearhop S, Thompson DR, Phillips RA, Waldron S, Hamer KC, Gray CM, Votier SC, Ross BP, Furness RW (2001) Annual variation in great skua diets: the importance of commercial fisheries and predation on seabirds revealed by combining dietary analyses. Condor 103:802-809

Bradstreet MSW, Brown RGB (1985) Feeding ecology of the Atlantic Alcidae. In: Nettleship DN, Birkhead TR (eds) The Atlantic Alcidae. Academic Press, London, pp 264-318

Brown KM, Ewins PJ (1996) Technique-dependent biases in determination of diet composition: an example with ring-billed gulls. Condor 98:34-41

Davoren GK, Burger AE (1999) Difference in prey selection and behaviour during self-feeding and chick provisioning in rhinoceros auklets. Anim Ecol 58:853-863

Dierschke A-K, Hüppop O (2003) Langfristige Veränderungen in der Ernährung von Silbermöwen (Larus argentatus) auf Helgoland unter dem Einfluss der Fischerei mit Vergleichen zur Heringsmöwe (Larus fuscus). Seevögel 24:3-15

Erikstad KE (1990) Winter diets of four seabird species in the Barents Sea after a crash in the capelin stock. Pol Biol 10:69-627

Erikstad KE, Vader W (1989) Capelin selection by Common and Brunnich's Guillemots during the prelaying season. Ornis Scand 20:151-155

Erikstad KE, Reiertsen TK, Anker-Nilssen T, Barrett RT, Lorentsen S-H, Strøm H, Systad GH (2007) Levedyktighetsanalyser for norske lomvibestander, NINA Rap 240, Trondheim

Furness RW, Barrett RT (1985) The food requirements and ecological relationships of a seabird community in north Norway. Ornis Scand 16:305-313

Gaston AJ, Jones IL (1998) Bird families of the world. The Auks Alcidae. Oxford University Press, Oxford

Härkonen T (1986) Guide to the otoliths of the bony fishes of the Northeast Atlantic. Danbiu, Hellerup

Hedd A, Montevecchi WA (2006) Diet and trophic position of Leach's storm-petrel during breeding and molt, inferred from stable isotope analysis of feathers. Mar Ecol Prog Ser 322: 291-301

Hopkins CCE, Nilssen EM (1991) The rise and fall of the Barents Sea capelin (Mallotus villosus): a multivariate scenario. Polar Res 10:535-546

Jobling M, Breiby A (1986) The use and abuse of fish otoliths in studies of feeding habits of marine piscivores. Sarsia 71:265-274

Johnstone IG, Harris MP, Wanless S, Graves JA (1990) The usefulness of pellets for assessing the diet of adult shags Phalacrocorax aristotelis. Bird Study 37:5-11

Kålås JA, Viken Å, Bakken T (eds) (2006) Norsk Rødliste 2006-2006 Norwegian red list. Artsdatabanken, Trondheim

Krasnov JV, Barrett RT (1995) Large-scale interactions among seabirds, their prey and humans in the southern Barents Sea. In: Skjoldal HR, Hopkins C, Erikstad KE, Leinaas HP (eds) Ecology of fjords and coastal waters. Elsevier, Amsterdam, pp 443-456
Lorentsen S-H, Anker-Nilssen T (1999) Diet of common murres wintering in northern Skagerrak during 1988-1990: variation with sex, age and season. Waterbirds 22:80-89

McLeay LJ, Page B, Goldsworthy SD, Ward TM, Paton DC (2009) Size matters: variation in the diet of chick and adult crested terns. Mar Biol 156:1765-1780

Mehl S (1991) The northeast Arctic cod stock's place in the Barents Sea ecosystem in the 1980s: an overview. Polar Res 10:525-534

Mehlum F (2001) Crustaceans in the diet of adult common and Brünnich's guillemots Uria aalge and U. lomvia in the Barents Sea during the breeding period. Mar Ornithol 29:19-22

Orians GH, Pearson NE (1979) On the theory of central place foraging. In: Horn DJ, Mitchell RD, Stairs GR (eds) Analysis of ecological systems. Ohio State University Press, Columbus, pp 154-177

Österblom H, Olsson O, Bleckner T, Furness RW (2008) Junk-food in marine ecosystems. Oikos 117:967-977

Ouwehand J, Leopold MF, Camphuysen CJ (2004) A comparative study of the diets of guillemots Uria aalge and razorbills Alca torda killed during the Tricolor oil incident in the south-eastern North Sea in January 2003. Atl Seabirds 6:147-164

Pedersen J, Hislop JRG (2001) Seasonal variations in the energy density of fishes in the North Sea. J Fish Biol 59:380-389

Shealer DA (2002) Foraging behaviour and food of seabirds. In: Schreiber EA, Burger J (eds) Biology of marine birds. CRC Press, Boca Raton, pp 137-177

Sonntag N, Hüppop O (2005) Snacks from the depth: summer and winter diet of common guillemots Uria aalge around the Island of Helgoland. Atl Seabirds 7:1-14

Swennen C, Duiven P (1977) Size of food objects of three fish-eating seabird species: Uria aalge, Alca torda, and Fratercula arctica (Aves, Alcidae). Neth J Sea Res 11:92-98

Thaxter CB, Daunt F, Hamer KC, Wtanuki Y, Harris MP, Grémillet D, Peters G, Wanless S (2009) Sex-specific food provisioning in a monomorphic seabird, the common guillemot Uria aalge: nest defence, foraging efficiency or parental effort? J Avian Biol 40:75-84

Vader W, Barrett RT, Erikstad KE, Strann K-B (1990) Differential responses of common and thick-billed murres to a crash in the capelin stock in the southern Barents Sea. Stud Avian Biol $14: 175-180$

Watt J, Pierce GJ, Boyle PR (1997) Guide to the identification of North Sea fish using premaxillae and vertebrae, ICES Coop Res Rep No. 220, ICES, Copenhagen

Wilson LJ, Daunt F, Wanless S (2004) Self-feeding and chickprovisioning diet differ in the common guillemot Uria aalge. Ardea 92:197-208

Woo KJ, Elliott KH, Davidson M, Gaston AJ, Davoren GK (2008) Individual specialization in diet by a generalist marine predator reflects specialization in foraging behaviour. J Anim Ecol 77:1082-1091

Ydenberg R (1994) The behavioural ecology of provisioning in birds. Ecoscience 1:1-14

Zar JH (1999) Biostatistical analysis. Prentice Hall, Upper Saddle River 